\title{
The Amun Cult and Its Development in Nubia a
}

Luc Gabolde

The Oxford Handbook of Ancient Nubia

Edited by Geoff Emberling and Bruce Beyer Williams

Print Publication Date: Feb 2021

Subject: Archaeology, Archaeology of Africa, Egyptian Archaeology

Online Publication Date: Jan 2021 DOI: 10.1093/oxfordhb/9780190496272.013.19

\begin{abstract}
Keywords
This chapter examines the origins of the god Amun, of his name, his ram-headed form, and their connections to Nubia, which seem to have been overestimated. Amun appears to be the major deity worshipped in Nubia after the Egyptian conquest of the New Kingdom. Considered to be a national and universal god, he became the protector of Kushite kingship, spread through the religious conversion of the Kushite elite to Egyptian religious beliefs. Amun is a solarized deity figured as a man (occasionally ithyphallic) with a two-feather headdress primarily as the god of Karnak, and as a ram-headed deity as that of Jebel Barkal. He may also appear as a bull, a goose, and more questionably as a crocodile or a cobra. His main sacred cities were Napata, Pnubs, Kawa, Sanam, and Tara. He is occasionally accompanied by Mut, Khonsu, Satis, and Anukis.
\end{abstract}

Keywords: Egypt, Kush, New Kingdom, Napatan, deities

\section{The Origins of Amun and Connections with Nu- bia}

THE theology of Amun is a combination of three different concepts blended together by the Theban rulers of the Egyptian 11th Dynasty:

1. the concept of the "Hidden One" known as far back as the Pyramid Texts (or earlier);

2. the solar deity Ra, provider of royal legitimacy;

3. the iconography and liturgies of ithyphallic Min of Koptos.

Though Amun is clearly a Theban composition (Gabolde 2018b: pp. 565-66), it has sometimes been hypothesized that some aspects of the deity may have originated from the Sudan. As a matter of fact, the kings of the 25th Egypto-Kushite Dynasty and their Napatan 
successors promoted myths, sometimes traceable back to Ramesside times, which make clear allusions to some potential Nubian roots of the deity at Jebel Barkal. ${ }^{1}$

Although there is no doubt that from the New Kingdom onwards some mythical connections were drawn between Amun and Nubia, nothing of this kind is attested in Kush during the Middle Kingdom when the god was first worshipped at Thebes, or in the Old Kingdom when the divine concept of the "Hidden One/Hidden of Name" appears in the Pyramid Texts.

(p. 344) Moreover, it should be noted that the Middle Kingdom conquest of Lower Nubia had apparently not led to any introduction of the cult of Amun in the land of Kush. Setting aside the onomastic, the god is not encountered in Egyptian inscriptions of Middle Kingdom Nubia, except one isolated mention at Jebel Turob (H. Smith 1972:48). A private monument of the 13th Dynasty from Buhen (H. Smith 1976:5-6, pl. I,1) does mention, in the offerings-formula, Amun-R[a (?)], Sebek, Isis, and Horus, but it does not prove the existence of a cult of the god on this site. His potential mention and representation on the recently revealed stela in the name of Senusret III at Nauri is to be dated to the New Kingdom as convincingly proposed by the editor (Rondot 2008).

Amun appears thus to be peculiarly insignificant among the Egyptian deities attested in Nubia at this early time. Nor was Amun considered by the Egyptian rulers to be a conquering deity: it is Montu, not Amun, who is thanked for the victories on the stela recording Senusret I's campaign in Nubia (stela Florence 2540). This noticeable absence may be explained by the fact that the goal of the conquest was to secure the frontier, not to implement a colonization of the land aiming at a cultural or religious expansion. The real emergence of Amun in Nubia dates to the New Kingdom. It more or less followed in space and time the advances of pharaoh's armies into the land of Kush.

\section{The Name of the God: Egyptian Rather than Nubian}

The name of the god has been sometimes regarded as having a potential Nubian origin and being connected with the root aman meaning "water" in Old Nubian (Lepsius 1880: 268-69) as well as in the Nobiin language (Rilly 2010:445). However, this hypothesis is not relevant for the question of the god's origins since these languages are millennia more recent than the appearance of Amun. On the other hand, the link between the name of Amun and the Egyptian concept of "hidden" (imn) is well acknowledged by the Kushites themselves (Tanwetamani; Eide et al. 1994:198-99(29)) and can easily be traced back to the Pyramid Texts.

\section{The Ram-Headed Amun: Origins}

The Ram-headed Amun was considered by the Kushites themselves to be the local form of the god of Karnak (Kormysheva 1994, 2004:111-12).

Page 2 of 28

PRINTED FROM OXFORD HANDBOOKS ONLINE (www.oxfordhandbooks.com). (c) Oxford University Press, 2018. All Rights Reserved. Under the terms of the licence agreement, an individual user may print out a PDF of a single chapter of a title in Oxford Handbooks Online for personal use (for details see Privacy Policy and Legal Notice). 
On a zoological level, it seems that rams of the two species Ovis longipes paleoaegyptiaca (with wavy horizontal horns) and Ovis aries platyura aegyptiaca (with horns wound (p. 345) around the ears) were present in early history of Nubia from where they could have spread to Egypt (see Chaix and Grant 1987 and Bickel 1991, though Boessneck 1988 :72-73 claims that the Ovis aries could have been imported from the Middle East).

The most ancient exemplar of a ram-headed ("criocephalic") Amun in Nubia as well as in Egypt is carved on the sacred rock of Kurgus and dates to the reign of Thutmose I (Figs. 19.1-2) (Davies 2017:71, figs. 6-7). As the Nubian kingdom of Kerma was a society rooted in pastoralism (Bradley 2013; Emberling 2014; Doyen and Gabolde 2017), the existence of a Nubian ram-deity pre-existing the New Kingdom Egyptian conquest has occasionally been inferred from some other-in fact extremely scarce-clues (Wildung 1984:181-82; Kormysheva 2004:109; Török 2009:151-52), though, unlike bovids, ovicaprids were only rarely depicted in Nubian artistic productions (Kleinitz 2012:33). ${ }^{2}$

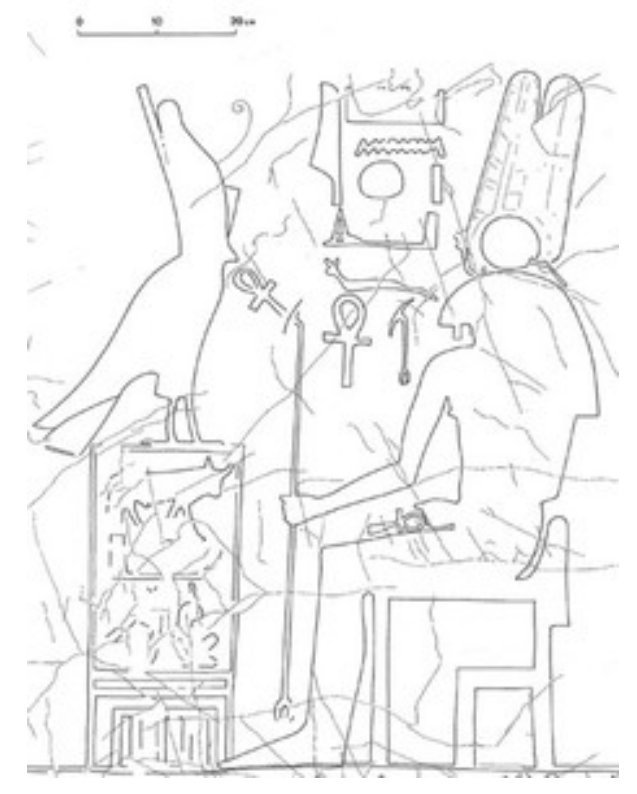

Figure 19.1 Ram-Headed Amun on the rock stela of Thutmose I at Kurgus (after Davies 2017:71, figs. 6 and 7. Courtesy Vivian Davies). 


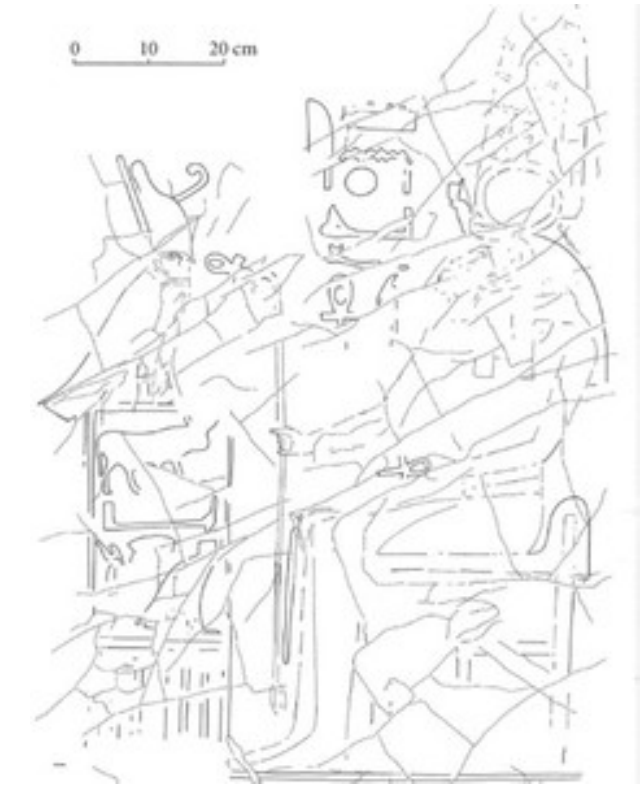

Figure 19.2 Ram-Headed Amun on the rock stela of Thutmose III at Kurgus (after Davies 2017:71, figs. 6 and 7. Courtesy Vivian Davies).

The clues remain fragile and fail to constitute a definite proof of a pre-existing ovine cult in Kush, though the possibility cannot be totally discarded. Indeed it would be quite plausible that the prevalence of ram-headed Amun in the land of Kush had resulted from the conjunction of Egyptian and Kushite religious traditions (Valbelle and Bonnet 2003:29697) promoted by two peoples who, after tough fights, were keen to find common concepts in each other's cultures and beliefs.

Pamminger (1992:109) suggested that the Luxor temple had been founded in order to provide the ram-headed Nubian Amun of Napata with an Egyptian home at Thebes. However, as he also noted, Amenhotep III's Amun at Luxor is never the typical criocephalic deity of Nubia. Neither is he designated there with a specific relation with Kush. Moreover, when the temple was founded, under the reign of Ahmose (Urk. IV:25, 9-11), the conquest of Nubia was not achieved, Napata had not yet been reached, and the supposed criocephalic aspect of the local god was still unknown to the Egyptians.

\section{The Cult of the Ram-Headed Amun}

As mentioned, the ram-headed aspect of Amun appears at Kurgus at the Egyptian initiative of Thutmose I (copied by Thutmose III), with the two feathers and the sun disk. (p. 346) (p. 347) It has been suggested that he could represent Amun of Napata (Pamminger 1992:106 n. 148). This ovine aspect was also shared by Amun of Pnubs, at least after the Amarna episode (Valbelle 2003a:192-93), mainly figured as a criocephalic sphinx under a jujube tree. At Napata, the year 47 stela of Thutmose III at Barkal is so damaged that the image of the god is unrecognizable (see however the plausible restoration of Kendall, this volume), but the ram-headed deity is present on another stela from 
the courtyard of B 501 sometimes attributed to the same king (Török 2002:48 n. 35; Dunham 1970:43 no. 20-2-166, pl. XLVII/H but Goedicke 1972, dates the stela to the Ramesside period). The criocephalic Amun became the basic representation of Amun as a Nubian deity: Amun of Napata (e.g., Grimal 1981: pls. I, V, VIII, X; Kormysheva 2004:11112), of Kawa (Macadam 1955: pl. XVIIIa), of Naga (Kröper et al. 2011:16, 22, 25, 26), of Musawwarat es-Sufra, of Meroe (Hintze 1971: pl. 41) among many others, whereas the original Amun-Ra of Karnak ("Lord of the Thrones of the Two Lands, who presides over Karnak”) usually kept his genuine anthropomorphic aspect in Kush (e.g., Hintze 1971: pl. 24).

The recumbent ram of Amun is paramount on dromoi (processional ways into temples). The animal standing on its legs was venerated as rhny, "ram," or labelled Amun-Ra in "popular" religion (e.g., Habachi 1960:51; Valbelle and Bonnet 2003:300-301, figs. 3-4, 6); however, like in Egypt (except in the Late Period: see Fabre 2012), there is no clue that a sacred living ram was ever bred and worshiped as the divine earthly embodiment of Amun: so far, no necropolis for the sacred animal was ever found, nor is any priesthood ever attested for his cult; the incarnation of the god on the earth was apparently the king. It is the occasional merging of Amun with Khnum of Elephantine which, in the late period, in the area of Elephantine, eventually resulted in the worship of the ram as a sacred animal of Khnum-Amun (Kormysheva 2004:112-13; and overall Yoyotte 2005:479).

Other animals were also potentially associated with Amun in Nubia: bulls, ${ }^{3}$ geese, ${ }^{4}$ crocodiles, ${ }^{5}$ and cobras. ${ }^{6}$

\section{A Solarized Deity}

As in Egypt, the Nubian Amun was solarized (Amun-Ra) and, occasionally, merged with Horakhty (Rameses II, Horakhty-Amun, Wadi es-Sebua: see Gauthier 1912:168-69; Aramatelqo "beloved of Amun-Ra-Harakhty": see Eide et al. 1994:290-91; Török 2002:303) and Atum (Priese 1974:222-23). Amun-Ra-Horakhty-Atum is attested on the statue of Bakenwerel (KRI 6:528,7; Dunham 1970:32, Figure 26) and in inscriptions from B 501 of Menma'atre-setepenimen Aktisanes (?) (Khartoum 5227; Dunham 1970:34, pl. XXXVII). It has also been suggested that the so-called Sun Temple M250 at Meroe was the place of the unification of the Amun worshipped in Meroe City with Ra (Török 2002:220). For the solar rituals, a specific dais-room was created, following a tradition of solar altars attested from the Middle Kingdom (p. 348) onwards at Karnak (Gabolde 2018b: 247-58) and present in most of the funerary New Kingdom Theban temples. In Sudan, this room was shaped like the wabet of late Egyptian temples (Wolf 2006:242-43; Coppens 2007:215-19; Rocheleau 2008:77). 


\section{The Anthropomorphic Amun}

The Theban Amun was represented as a human deity with mortar-shaped crown and two high feathers (Török 1997a:303). It is under this aspect that he appeared before the Amarna period at Kerma-Pnubs (Valbelle 2003a:202 Figure 7, 203, Figure 8). It is also the (p. 349) image of the god at Sai (Figure 19.3), at Soleb (Schiff-Giorgini et al. 1998: pl. 28), at Kawa under Tutankhamun (Macadam 1955: pl. V), and at Sanam (Griffith 1922: pls. XIII, XX,4, XLVIII), though in the latter two sites he may also be represented as criocephalic (Sanam: Griffith 1922: pls. XXXVII, LIV,5) or as a criosphinx (Kawa: Macadam 1955: pl. IV).

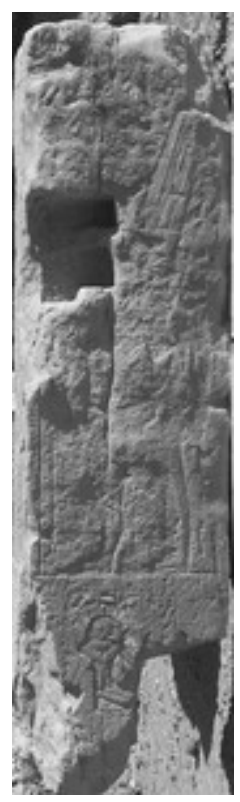

Figure 19.3 Amun on a pillar of Thutmose III at Sai Island, restored after Amarnan chiseling out. Photograph: L. Gabolde.

Occasionally the feathers are stuck in a diadem or a ribbon prolonged by a vertical tail. A uraeus adorns the forepart of the mortar in Meroitic representations (e.g., Naga: Griffith and Crowfoot 1911: pls. XXI and XXIII; Musawwarat es-Sufra: Hintze 1971:25; Figure 19.4), but it is seldom attested in Egypt (Gabolde 2018b: 544-45). A solar disk appears at the base of the feathers in the Ramesside period (e.g., Habachi 1960: pl. XIV) and is paramount in the Napatan and Meroitic ages. 


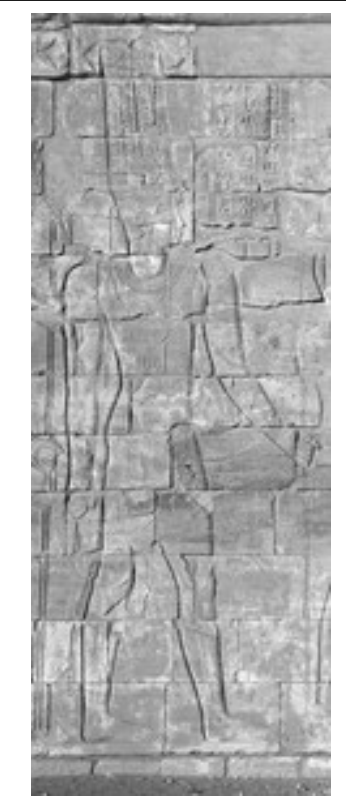

Figure 19.4 Amun at Musawwarat es-Sufra. Photograph: C. Näser.

The ithyphallic Amun is represented at Soleb (Schiff-Giorgini et al. 1998: pls. 122-25) and Amun of Ope is attested in funerary inscriptions (as Mnp/Amnp cf. Eide et al. 1996:670, 675), once as an ithyphallic deity in B 300 at Napata (Taharqo, LD V:pl. 10) and maybe another time at Naga (Griffith and Crowfoot 1911: pl. XXIII; Kröper et al. 2011:157). It is not clear whether Amun of Ope designates Amun of Luxor or-more likely-that of Djeme (Medinet Habu), that is, the god Amenope (Quaegebeur 1986:104-107). It has been suggested that Amun-bull-of-Nubia of Sanam could be equated with Kamutef and would have played locally the role of Amun of Djeme (Török 1997a:304 with evolution in Török 2002: 77 and n. 172; Guermeur 2005:524). His cult was transferred to Meroe where he is regularly mentioned as "Amun of Ope in Meroe (City)."

\section{Amuns of Nubia}

\section{The Holy Cities of Amun in the Area of Napata}

After the Egyptian conquest of Nubia during the New Kingdom, temples to Amun were founded in the controlled territories. Under Egyptian occupation, the center of the "Amunian" faith remained Thebes and the Nubian Amuns were considered his peripheral emanations. With the 25th Dynasty a shift appears: almost equal importance is assigned to Thebes and to Napata. Later, the Napatan and Meroitic theological centers of "Amunism" remained at Napata, progressively identified with a more and more mythical Thebes. The cult of Amun was focused in Nubia on three and then four holy cities: Napata (which progressively replaced Karnak as source of legitimacy), Pnubs, Kawa, and then Sanam (Eide et al. 1994:223(34): Anlamani) or Tara (Eide et al. 1996:442-43(78): Harsiyotef). These distinct Amuns of Nubia also had chapels in the other towns, like Amun of 


\section{The Amun Cult and Its Development in Nubia}

Pnubs at B 300 at Barkal and at Sanam (Valbelle 2003a:192-94, 209) and (p. 350) Amun of Napata at Sanam (Guermeur 2005:524). Later, equivalents in the Butana region were promoted: Meroe housing Amun of Thebes of Napata (?), Amun of Meroe (M 260), and Amun of Ope (Amnp; temple not identified), Naga also housing Amun of the city of Thebes, Amni Notete and Amun of Naga Amni Tolqtete, as well as Amni Berote (Amun of Bero probably Meroe) and Amni Mede[w]i[te], Amun of Medewi (Török 2002:244; Wolf 2006:240).

\section{Napata}

The most prominent Amun in Kush was certainly that of Jebel Barkal. At the foot of the holy mountain of the local Kushite populations, extraordinarily named nswt t3wy ("Nesut Tawy" or "Throne of the Two Lands" as transcribed by the Egyptians), Thutmose III erected, before his year 47, "an eternal repository chapel-hnw" for "Amun Lord of the Thrones of the Two Lands/who dwells in the pure mountain" inside a fortified stronghold (Urk. IV: $1228,12-14)$, probably where, later on, the great Napatan temple of Amun B 500 would stand. In B 500 the oldest architectural remains seem to date to Tutankhamun if we exclude pre-Amarna undated brick structures found on the spot (Kendall et al. 2017:150, 170-72). Horemheb (Kendall et al. 2017:173-74) and Sety I (B 503) also left architectural traces. Contributions of Rameses II, Piye (Piankhy), Taharqo, Tanwetamani, Amanishakheto, Amanitore, Natakamani, and Arnekhamani are recorded (Török 2002:48-50, 69, 205, 297, 313; Guermeur 2005:524; Rocheleau 2008:33). In the vicinity of B 500, Thutmose IV seems to have dedicated a temple to Ra-Horakhty and/or Amun (B 600: Kendall and Wolf 2011). Jebel Barkal B 700 was dedicated to Amun in Napatan and Meroitic times: Atlanersa and Senkamanisken left their names (Török 2002:157-72; Rocheleau 2008:34). Jebel Barkal B 800, dedicated to Amun by Kashta or Piye (Piankhy), was modified by Anlamani. It was destroyed under Aspelta (Török 2002:50-53, 259-60; Rocheleau 2008:35-36).

At Napata, Amun, as an emanation of Karnak's god, kept his Theban epithets $n b$ nswt t3wy, "Lord of the Thrones of the Two Lands," and hnty Ipt-swt, "preeminent in Karnak," augmented with local designation: $n N p t / h r y-i ̉ b ~ d w w ' b / n t \underline{t}{ }^{\prime}{ }^{\prime} 3$ hnty T3-Stt, "of Napata/who dwells in the Pure Mountain/great god preeminent in the Bow-Land" (e.g., Eide et al. 1996:473(84): Nastasen). The site of Barkal itself was considered "the Karnak of Amun of Napata" (Eide et al. 1996:444(78): Harsiyotef) and Nastasen designates it Ipt-Swt PrNbw, "Karnak's House of Gold," or as Ipt-Swt Nbw, "Karnak of Gold" (Eide et al. 1996: $443,444(78), 478,480(84))$, while Napata is clearly assimilated with Thebes (in Eide et al. 1996:488(84)).

\section{Pnubs}

As the ancient Kushite capital of the kingdom, Kerma/Pnubs (Dokki Gel) was duly provided with temples to Amun-Ra of Pnubs, Pa-Nebes/Hery-ib Pa-Nebes (Valbelle 2003a; (p. 351) Guermeur 2005:501-508; Rocheleau 2008:21). The oldest remains date to Thutmose I or II and a temple from Thutmose IV is also attested there (Bonnet 2003:209; Valbelle 2003b:229). Napatan and Meroitic sanctuaries left traces mentioning Taharqo, 
Shabaqo, Amannote-erike, and Amanikhareqerem (Valbelle and Bonnet 2000; Valbelle 2003b:233). The deity worshipped in the temples erected in the New Kingdom and then rebuilt by Taharqo at Tabo on Argo Island remains unknown (Bonnet 2011), but it is definitely not Amun of Pnubs as previously thought (Jacquet Gordon et al. 1969; Hein 1991: 63; Rocheleau 2008:25, 76-77).

\section{Kawa}

In Kawa Temple A, Amun is named the "Lion on the terrace who dwells at Gem-pa-aten," represented as an anthropomorphic deity (Macadam 1949: pl. II, V; Macadam 1955: pl. 3) or a criosphinx (Macadam 1955: pl. 4). The temple was possibly founded by Amenhotep III (?) and certainly built by Tutankhamun (Török 2002:139-42; Guermeur 2005:509-10; Rocheleau 2008:26). Kawa Temple T was dedicated to Amun "Lion on the terrace who dwells at Gematen" by Taharqo (Török 2002:80-128, 282-97; Guermeur 2005:511-18; Rocheleau 2008:28). Later on, Temple Kawa B to Amun "who dwells at Gematen" was erected by Harsiyotef (?) and enlarged in Meroitic times (Török 2002:148-56, 282; Guermeur 2005:510; Rocheleau 2008:27). The god is then mainly criocephalic (Macadam 1949: pl. XXIVd; Macadam 1955: pls. 6, 8, 10, 14, 16).

\section{Sanam}

At Sanam, Amun was "Bull of Nubia" (T3-Sty) in a temple built by Taharqo (Griffith 1922; Török 2002:134-39, 282; Guermeur 2005:519-23; Rocheleau 2008:32).

\section{Tara}

In the vicinity of Napata (?), the city of Tara/Taret/Tale devoted to Bastet used to house a temple to Amun of Tara, inserted in the coronation journey by Harsiyotef, apparently as a substitute to Sanam (Eide et al. 1996:443).

\section{The Other Cult Places of Amun}

\section{Amun Temples in Nubia}

The early dissemination of the "Amunian" cults among the Kushites left few traces at Debeira where local princes converted to Egyptian religious beliefs occasionally (p. 352) addressed their prayers to "Amun-Ra, Lord of the Thrones of the Two Lands" (and to "Horus, lord of Buhen"; Säve-Söderbergh 1960:28, Figure 2).

Apart from the four holy cities mentioned above, the list of the sanctuaries dedicated to Amun can be summarized as follows (combining the data of Hein 1991; Török 2002; Guermeur 2005; Rocheleau 2008):

- Debod: Amun (Anthropomorphic and criocephalic) associated with Mahes-lion; Sety II (?) Ergamenes, Adikhalamani, Ptolemy VI, Roman (Hein 1991:5; Guermeur 2005: 476-81; Rocheleau 2008:10). 
- Takhompso: Amun of Takhompso; Taharqo (Guermeur 2005:482-84).

- Beit el Wali: Amun "Lord of the Thrones of the Two Lands, preeminent at Karnak, who dwells/preeminent in/Lord of Ta-sety"; Sety I, Rameses II, Merenptah, Sety II (Hein 1991:5).

- Wadi es-Sebua: Amun 33 nb mtnw ("Lord of the tracks"); Rameses II and other Ramessides (Guermeur 2005:485-90).

- Amada: Amun-Ra "Lord of the Thrones of the Two Lands" and Ra-Harakhty; Amenhotep II, Thutmose IV, Sety I (Brandt 2000:285; Rocheleau 2008:11).

- Abu Simbel: Amun-Ra her-ib (KRI II:749,1); Amun of Abu Oda (invited deity), AmunRa hrry-ỉb t3-sty (KRI II:750,1, Amun of Nubia), Amun of Napata (invited deity) nb nswt T3wy hrry-ỉb p3 $\underline{d} w$-w`b Npt (KRI II, 750,15-16); Rameses II.

- Abu Oda: Amun of Karnak and Amun-hry ("satisfied")/hry-ỉb Amun-ḥry-ỉb, "Who resides in 'Amun-Who-Is-Here' (= Abu Oda)" (shared with Thoth); Horemheb (Guermeur 2005:492-93).

- Aksha: Amun-Ra hry-ỉb pr wsr-m'3t R'stp.n $R^{\prime}$ (shared with Rameses II deified); Sety

I, Rameses II (Guermeur 2005:494-95; Rocheleau 2008:15).

- Amara East: Amun; Meroitic, Natakamani, Amanitore (Török 2002:254-55; Rocheleau 2008:16).

- Amara West: Amun of Perem (?); Sety I, Rameses II (Guermeur 2005:495-97; Rocheleau 2008:17).

- Sai: Amun-Ra nb-nswt-T3wy, nswt-ntrw, nb pt, hrry-ỉb t3-Stỉ; [Amenhotep I ?] Thutmose III, Amenhotep II, Amenhotep III (Thill 1997:112-13; Rocheleau 2008:18; Azim and Carlotti 2011; Davies 2014:7-9; Doyen and Gabolde 2017:151, Figure 2).

- Sedeinga: Amun ḥry-ỉb ḥwt-Tỉyỉ (invited deity); Amenhotep III (Rilly and Francigny 2013:64-65).

- Soleb: Amun-Ra Nb-nswt-T3wy hry-ỉb mnnw h̆'-m-M3`t (sharing with deified Amenhotep III); Amenhotep III (Guermeur 2005:498; Rocheleau 2008:19).

- Sesebi: Amun-Ra and Theban Triad; Amenhotep IV, Sety I (Guermeur 2005:499-500; Rocheleau 2008:20).

\section{Amun Temples in the Isle of Meroe and Nearby}

The first buildings at Meroe date to the early 25th Dynasty (Török 1997b:25; Wenig 2013: 162):

(p. 353)

- Dangeil Kôm II: Amun; Amanitore, Natakamani (Rocheleau 2008:37; Anderson and Salah Mohamed Ahmed 2013).

- Meroe, double temple KC 104: Amun (?); Meroitic, Amanitore, Arikhankaror (Rocheleau 2008:39). Meroe M 260: Amun Nete; Meroitic, Amanishakheto, Amanikhabale, Amanitore, and Natakamani (Török 2002:314-30; Rocheleau 2008:41). Meroe M292 
and M298 [early Amun Temple ?]: [Amun ?]; Napatan and early Meroitic, cartouches of Senkamanisken, Anlamani, Queen Nasalsa, Aspelta, Aramatelqo, Malonaqen, AmaniNatki, Karkamani, Amaniastbarqo, Siaspiqo, Talakhamani, and Amanislo (Török 2002: 315; Rocheleau 2008:42).

- Musawwarat es-Sufra, great enclosure, T 100 Amun (invited deity?); (Wenig 2001; Török 2002:173; Rocheleau 2008:65). Musawwarat es-Sufra, Löwentempel: Amun in subordinate position regarding Apedemak (Hintze 1971: pls. 25, 41, 59, 63, 79, 81, 85, 89, 93, 97; Török 2002:187-200).

- El Hassa: Amun of Tabakha; Amanikhareqerem, Meroitic (Rondot 2012).

- Muweis (Baud 2014:775).

- Wad Ben Naga South Temple Kom C WBN 300: Amun (sharing with Isis and Hathor); Meroitic, Natakamani Amanitore (Rocheleau 2008:48; Onderka 2014).

- Naga N 100: Amun of Tolkte; Meroitic, Natakamani, Amanitore, and Prince Arkhamani (Török 2002:241-53). Naga N 500: Amun and invited deities; Meroitic kandake Shanakdakhete (Rocheleau 2008:55; Kröper et al. 2011:16-26).

\section{Entourage of Amun}

Amun, as in Egypt, was accompanied by a consort: Mut. At Napata she was eventually assimilated to lion-headed Hathor-Tefnut and accompanied by her son Khonsu. As a criocephalic Nubian god, Amun was associated at Kawa with the goddesses Anukis and Satis (Macadam 1955: pls. VI, XVII), or with Anukis alone (Macadam 1949: pls. 6, 8, 1955: pl. XVIII) but, as anthropomorphic Amun of Karnak with Mut (Macadam 1949: pls. 6, 8, 1955: pl. XVIII). Amun appears with Satis at Sai Island as well as at Musawwarat es-Sufra (Hintze 1971: pl. 41). Mentions of Amunet are scarce and not specifically associated with her consort (Gauthier 1912:168, 170).

\section{Politico-religious Background of the Expansion of Amun's Cult}

The nature of the religion of Amun in Nubia is still an object of investigations; however, provisional conclusions can be drawn from the available documentation.

(p. 354) The diffusion of Amun's cult in Nubia seems to be characterized by a genuine conversion of the Kushites to Egyptian religious beliefs (Yellin 1995; Török 1997a:126, 2002: 51-53), applied to a form of Amun (ram-headed) characteristic of Nubia, or considered as a local deity (Török 1997a:263). With time, the religious practices and beliefs incorporated more and more Kushite features. In that respect, the adoption of the Egyptian religion should in no way be considered to be acculturation: from its origins, Kushite culture was 


\section{The Amun Cult and Its Development in Nubia}

quite assertive (S. Smith 1998:256-57; but nuanced view in Kemp 1997) and remained vivid as proved by the extensive survival of its language.

The conversion was mainly led by the Kushite elite and seems to have affected the general population much less than the members of the court (although Török 2009:210-11 suggests a wider adoption of the Amun cult).

Although the adoption of Egyptian beliefs began under the New Kingdom Egyptian occupation, the shift to an official Kushite state religion seems to have occurred in a short span of time (around one generation) as shown by the fast change of funeral practices at El-Kurru (Török 1997a:126; Kendall 1999; Morkot 2003).

The converted Kushite leaders promoted themselves as champions of Amun, as initiators of a religious renewal, and as authentic guardians of "Amunism." This myth of authenticity was promoted by Kashta and Piye (Piankhy) and was later regularly revived (see Agartharchides' record of the Ethiopian origins of Egypt, Eide et al. 1996:645(142)).

As the Egyptian gods, including Amun, supposedly understood and read exclusively the Egyptian language and script, they were per force addressed by the Kushite rulers in Egyptian idiom, written in Egyptian hieroglyphic script.

The adoption of the Egyptian Amunian faith by the Nubians and the expansion of Amun's cult in Kush was accompanied (and sometimes preceded) by the spreading of other Egyptian beliefs (Isis, Horus, etc.), particularly the Osirian religion (Wenig 2013:160-61). Some of its funerary practices are evident in the tombs of the Nubian princes of Te-khet at Debeira or that of Hekanefer at Toshka. Similarly, the inscription of Queen Katimala at Semna (Eide et al. 1994:35-41(1); Darnell 2006; Collombert 2008; Ritner 2009:456-59) with the allusions to the pride of "serving among the servants of Amun" makes her a clear precursor of the Kushite 25th Dynasty.

With time, the original Egyptian documentation became less accessible or understood (Török in Eide et al. 1996:421) and the Kushite intelligentsia progressively reached a state of relative autonomy from the Egyptian sources of the cult after the adoption of the Meroitic script in cursive and in Meroitic hieroglyphic scripts in the second half of the 3rd century BCE (Török 1997a:344-45; Rilly in prep.).

The Kushite dynasty's involvement in Egyptian culture was mainly religious and institutional and the major politico-cultural investment of this royal family in Egypt passed through the appointment of some of its members to prominent religious functions-to that of the "divine votaresses of Amun" or high priesthood of Amun (Shabaqo's grandson Harkhebi, High Priest of Amun) on the one side, and to that of "pharaoh" on the (p. 355) other, whereas the high positions in administrations mainly remained in the hands of the Egyptian descendants of the great Theban families (Török 2009:351). This policy of the Kushite dynasty towards Amun's clerical hierarchy was also applied in Nubia: Alara committed to the cult of Amun, dedicating his sister to his temple at Kawa (Edwards 2004: 
116) or at Napata (Török 2002:51). Emblematic of this policy is the involvement of King Anlamani who states:

His Majesty gave his sisters, four women, to the gods, to be sistrum-players: one to Amûn of Napata (Jebel Barkal), one to Amen-Rê of "Finding-(the)-Aton" (Kawa), one to Amûn of Pnubs (Kerma), and one to Amen-Rê, bull of Bow-land/Nubia (Sanam), in order to shake the sistrum before them. (Kawa VIII-1, 24-25, Eide et al. 1994:223(34))

It is this adoption of the Egyptian religious and royal ideology that legitimized the hereditary royal authority of the Kushite rulers (Török 1995; Welsby 1996:74; Edwards 2004: 116).

\section{Amun's Characteristics, Prerogatives, and Functions in Nubia}

\section{Royal Legitimation}

As was already the case in Egypt (from its origins in the Middle Kingdom), Amun in Nubia was the warrant of royal legitimacy, mainly manifested during the coronation rites through:

- Election by means of repeated oracles (see Török, 1997:241-47). ${ }^{7}$ These oracles could be manifested through dreams (e.g., Tanwetamani: Eide et al. 1994:196-98(29); and Nastasen: Eide et al. 1996:475-79(84)); through signs of the divine images/bark during processions (Aspelta, election stela: Eide et al. 1996:235(37)); and in front of the permanent image in the holy of the holies (e.g., Amannote-erike: Eide et al. 1996: 415-16(71)). Oracles of the god are attested supporting either the designation of a king by one of his predecessors, like Amannote-erike being declared heir of Talakhamani (Török 1997a:193, 217 n. 114), or the selection of the king among his brothers by Amun (e.g., Aspelta: Eide et al. 1994:242(37)). Note that oracles of the god may also have concerned more secular affairs supposed to express the god's will as the necessity to implement restorations in a temple, as for Harsiyotef (Eide et al. 1996: 442(78); Török 1997a:385).

(p. 356) - Divine fatherhood. Nubian kings presented themselves as bodily sons of Amun, following an Egyptian tradition ${ }^{8}$ that is echoed by royal titularies such as that of Amannote-erike, "born of Amun of Thebes" (Kawa IX, 1. 21, Eide et al. 1996:401403(71)). The rulers' predestination to kingship from the womb of their mother, by means of a "miracle" (bi3), is also included (e.g., Taharqo: Eide et al. 1994:173 (24); or Amannote-erike: Eide et al. 1996:401(71)). However, the myth of the sonship from Amun was not really interwoven with the matrilinear tradition of the Kushite rulers through any myth of marriage to a god (i.e., a theogamy as attested for Hatshepsut and Amenhotep III). As son and embodiment of the god, the king's deeds were consid- 
ered to be deeds of the god: "it was you (Amun) that acted for me (Harsiyotef)" (Eide et al. 1996:448(78); also by Nastasen: Eide et al. 1996:493(84)).

- Coronation rituals and journey. The coronation of the king by Amun was supposed to occur at Napata, as attested by Piye’s (Piankhy's) Horus name ( $h$ ' $w-m-N p t$, "appearing crowned in Napata" (Eide et al. 1994:58(8)), but was also reiterated in Thebes, after the conquest of Egypt: h' $w$-m-W3st (Eide et al. 1994:54(7)). Napatan and Meroitic kings also followed the tradition of a coronation ceremony to be accomplished first at Napata, even if the accession of the king at the death of his predecessor had occurred at Meroe, like Anlamani (Török's comment in Eide et al. 1994:226; Török 1997a:232) or Amannote-erike (Eide et al. 1996:401-402(71)). In Nubia, the rites included a visit to other holy sanctuaries of Amun. Amannote-erike records that he was crowned at Napata then moved to Kawa, to Pnubs, and back to Kawa (Eide et al. 1996:406-11(71)) and Harsiyotef mentions his journey to Kawa and Pnubs or Tara (Eide et al. 1996:442-44 (78)).

\section{Amun Provider of Water and Flood}

The links between Amun and the waters (Nile, flood, water table, rains) was already well established in the Egyptian New Kingdom, the inundation being supposed to flow out of his feet (M. Gabolde 1995:254). Since the flood arrived from the far south, Amun played a key role in Nubia in the inundation process. ${ }^{9}$ Connections between the rams and the waters have frequently been put forward, the animal being credited with the capability to find springs under its hoofs (Leclant 1949:202-206). Several texts do insist that Amun controlled the liquid element. ${ }^{10}$

\section{Amun Dwelling in Caves and Mountains}

The significant number of rock-cut sanctuaries of Amun in Nubia (e.g., Abu Oda, Jebel Qeili, Abu Simbel) compared to the relatively rare rock-cut temples (speos temples) to Amun in Egypt leads us to conclude that in Nubia the god was considered as dwelling the mountains and cliffs and even embodied them (Adrom 2004; Williams 2006, 2007) (p. 357) and being thus the dehenet (cliff/escarpment) itself (Reisner 1931:82, 89-100, pls. V-VI; Eide et al. 1994:55(8); Gabolde and Rondot 2018:394-96). ${ }^{11}$

\section{Demiurge/Creator}

As had been observed in Egypt (only since the Second Intermediate Period onwards: Bickel 1994:160-61), Amun was considered to be a creator god in Nubia. ${ }^{12}$ Thus the temple was seen as the primeval mound, figuring the place of the world's creation (Török 1997a: 315). 


\section{Provider of Lands and Victories}

Amun in Nubia brought victories and new lands to the king and to his realm. Note that the presentation of bow and arrows by Amun to the king (Hintze 1971: pl. 89; Eide et al. 1996:408(71)), instead of the traditional scimitar (only mentioned in Eide et al. 1996: 404), appears to be a Kushite feature shared by Apedemak (see Eide et al. 1996:425; Török 2002:277 n. 71).

\section{Amun's Cult and Temple Organization in Kush}

\section{Cult Rituals}

The representations of daily or solemn rituals show that the liturgies followed the Egyptian prototype with local adaptations. Typically, conical offering breads were still in use (Anderson et al. 2007; Kröper et al. 2011:107). In Meroitic times, the offering ritual evolved with innovations like the specific ankh-shaped libation tables found in situ at Naga (Wildung 1999:306, Figure 3; 329, Figure 21a), El-Hassa (Rondot 2012:177-79), and Meroe (Näser 2004:232-33). The foundation rites were also modified with the deposit of old Egyptian genuine artifacts, unusually shaped natural stones, and prehistoric flints, considered to validate ancientness and sacredness (Kröper et al. 2011:97-100; Rondot 2012; Francigny and de Voogt 2014; Kendall 2017).

\section{Incomes and Offerings}

The restitution of lands to Amun of Pnubs and of Kawa, with all the people attached to them as described in the inscription of Amannote-erike (Eide et al. 1996:410-11(71)), shows that the income of Amun's temples continued to rely on land possession with the (p. 358) attached workers, cattle, and agricultural productions. The wealth of Amun endowments in liturgical vessels of gold, silver, bronze, temple furniture, raw material, incense myrrh, jewelry, lands, and cattle are proudly listed on temple inscriptions and stelae (e.g., Taharqo: Eide et al. 1994:165-71(24); Amannote-erike, already mentioned; Harsiyotef: Eide et al. 1996:444-47(78); Nastasen: Eide et al. 1996:473; 483-91(84)).

\section{Riverine and Processional Bark}

The riverine bark still existed and was represented at Sanam (Griffith 1922: pl. XXVI) as well as the portable bark, for processions (e.g., between Napata and Sanam, see Griffith 1922: pl. XXVII). The last is represented on its pedestal at Soleb (Schiff-Giorgini et al. 1998: pl. 49) and the carriers are still identifiable in the hypostyle of Temple $\mathrm{T}$ at Kawa (Macadam 1955: pls. XIV-XV). 


\section{Festivals}

In spite of the lack of festival calendars preserved in Kushite temples (Török 1997a:318) it seems that the dates of the festivals of Amun in Nubia had been adjusted with those of Amun at Thebes (especially to the 2nd and 3rd months of the akhet season devoted to the Opet festival; see Macadam 1949:48 n. 25). The multiplication of the god's appearances in procession on new festival days seems to have been a specific care of the Kushite rulers and a religious and political issue (e.g., Amannote-erike: Eide et al. 1996:410(71)).

\section{Priesthood}

As in Egypt, the cult was theoretically led by the king (who seems to have been given the role of the First Prophet: Török 1997a:316) and the rituals performed inside the temple remained unopen to the public and restricted to the priests' caste, the royal family, and notabilities. A Second, Third, and Fourth Prophet of Amun are attested in Nubia (e.g., at Sanam: Eide et al. 1994:264-65(39); at Kawa: Eide et al. 1994:220(34), Anlamani), as well as "pure" (wâb) or great-"pure"-priests and lector priests (e.g., Eide et al. 1996:41617(71), Amannote-erike). The feminine clergy is also represented with sistrum-players devoted to Amun of Napata, Kawa, Pnubs and Sanam (e.g., Anlamani, Eide et al. 1994: 223(34)), divine votaresses, mainly from the royal entourage (with Török's comment in Eide et al. 1994:240; 262).

\section{Temples}

The architecture of the Amun temples under Egyptian occupation (28th-30th Dynasties) reflected mainly New Kingdom Amunian architecture-with its diversity-(Hein 1991; (p. 359) Rocheleau 2008; Azim and Carlotti 2011). The architecture and decoration of the Napatan temples dedicated to Amun were also conceived in continuation of their Egyptian precursors and of their iconographical syntax (Török 2002:40-46) as expected in the case of the adoption of religious beliefs. In that respect it is quite significant to see the clear difference of architecture that distinguishes Apedemak's sanctuaries from Amun's. The Amun temples in Nubia are reviewed in Rocheleau (2008) and comprehensive studies of most of them are scrutinized in Török (2002). Their basic components can be summarized as follows:

- a processional way marked out with ram statues (Naga, Muweis, El Hassa, Meroe,

Dangeil, Napata, with prototype at Soleb);

- occasionally a bark repository (e.g., Naga, El-Hassa, etc.);

- a great altar off the axis (El-Hassa; Naga; Meroe M250; Kawa);

- a pylon preceding:

- a courtyard with a peristyle and/or

- a hypostyle hall;

- an offering hall; 
- a visiting deities hall;

- the sanctuary with:

- the naos (generally only the base survives) for the cultic statue which may have been of small dimensions. The naos was possibly of rounded shape like the Omphalos of Napata or base at El-Hassa (Rondot and Nogara in prep.);

- a dais-room possibly dedicated to Ra-Horakhty;

- side sacristies;

- and occasionally a contra temple (Naga, with ram statue and altar; and El-Hassa).

As a final statement, it appears that Nubia-a country regarded by the Egyptians as full of magic and mysteries-was certainly for them a place where their dynastic god Amun had some roots, an idea reinforced by the fact that the flood came from this far south. This theme was of course adopted and amplified under the Kushite, Napatan, and Meroitic rulers, once the local chiefs had embraced the Amunian faith in a genuine religious conversion, which included the use of a specific religious language and script: Egyptian. In that respect, this situation constitutes one of the first occurrences of a phenomenon later paralleled by Christianity's expansion backed by the liturgical use of Latin, or by Islam's spread along with its liturgical use of Arabic language.

\section{(р. 362) Abbreviations}

\section{KRI I-VIII}

Kitchen, K.A. 1975-90 Ramesside Inscriptions: Historical and Biographical. B.H. Blackwell.

Urk. IV

Sethe, K. 1906-1909 Urkunden der 18. Dynastie. Historische-biographische Urkunden 1-17. J.C. Hinrichs.

Helck, W.

1956-58 Urkunden der 18. Dynastie. Historische-biographische Urkunden 18-22.

Akademie Verlag.

\section{References Cited}

Adrom, F. 2004 Der Gipfel der Frömmigkeit? Überlegungen zur Semantik und religiosen Symbölik von t3-dhn.t. Lingua Aegyptia 12:1-20.

Anderson, J.R., A.C. D’Andrea, A. Logan, Salah Mohamed Ahmed 2007 Bread Moulds from the Amun Temple at Dangeil, Nile State-An Addendum. Sudan \& Nubia 11:89-93.

Anderson, J. and Salah Mohamed Ahmed 2013 Dangeil 2012: Sacred Ram-Avatar of the God Amun. Sudan \& Nubia 17:70-77. 
Azim, M. and J.-F. Carlotti 2011 Le temple A de l'île de Saï et ses abords. Cahier de Recherches de l'Institut de Papyrologie et d'Égyptologie de Lille 29:11-65.

Baud, M. 2014 Downtown Muweis-A Progress Report (2007-2011). In The Fourth Cataract and Beyond: Proceedings of the 12th International Conference for Nubian Studies, ed. J.R. Anderson and D.A. Welsby, pp. 763-82. British Museum Publications on Egypt and Sudan 1. Peeters.

Betz, H.D. 1992 The Greek Magical Papyri in Translation. University of Chicago Press.

Bickel, S. 1991 L'iconographie du dieu Khnoum. Bulletin de l'Institut Français d'Archéologie Orientale 91:55-67.

-_- 1994 La cosmogonie égyptienne avant le Nouvel Empire. Orbis Biblicus et Orientalis 134. Éditions Universitaires (Fribourg) and Vandenhoeck \& Ruprecht.

Boessneck, J. 1988 Die Tierwelt des alten Ägypten. C.H. Beck.

Bonnet, C. 1984 Les fouilles archéologiques de Kerma (Soudan). Genava n.s. 32:5-20.

- - 2003 Kerma. Rapport préliminaire sur les campagnes de 1999-2000 et 2000-2001. Genava n.s. 49:199-219.

-_- 2011 Le site archéologique de Tabo. Une nouvelle réflexion. In La pioche et la plume. Autour du Soudan, du Liban et de la Jordanie. Hommages archéologiques à Patrice Lenoble, ed. V. Rondot, F. Alpi, and F. Villeneuve, pp. 283-93. Presses de l’Université Paris-Sorbonne.

Bradley R.J. 2013 Nomads in the Archaeological Record: Case Studies in the Northern Provinces of the Sudan. Meroitica 13. Akademie Verlag.

Brandt, P.J. 2000 The Monuments of Seti I: Epigraphic, Historical, and Art Historical Analysis. Probleme der Ägyptologie 16. Brill.

Chaix, L. 1993 Les moutons décorés de Kerma (Soudan): problèmes d'interprétation. In Memorie della Società italiana di scienze naturali e del Museo civico di storia naturale di Milano 26(2):161-64.

(p. 363) Chaix, L. 2003 La découpe de l'agneau. Un rite funéraire à Kerma (Soudan) vers 2000 av. J.-C. In Sens dessus dessous. La recherche du sens en Préhistoire. Recueil de textes offerts à Jean Leclerc et Claude Masset. Revue Archéologique de Picardie n.s. 21:219-24. http://www.persee.fr/doc/pica_1272-6117_2003_hos_21_1_2649.

Chaix, L. and A. Grant 1987 A Study of a Prehistoric Population of Sheep (Ovis aries L.) from Kerma (Sudan): Archaeozoological and Archaeological Implications. Archaeozoologia 1:77-92.

Champollion, J.-F. 1844 Monuments de l'Egypte et de la Nubie. Notices descriptives conformes aux manuscrits autographes rédigés sur les lieux. Firmin Didot. 


\section{The Amun Cult and Its Development in Nubia}

Collombert, P. 2008 Par-delà Bien et Mal. L'inscription de la reine Katimala à Semna. Kush 19:185-218.

Coppens, F. 2007 The Wabet: Tradition and Innovation in Temples of the Ptolemaic and Roman Period. Czech Institute of Egyptology.

Coulon, L. and E. Jambon 2015 Cachette de Karnak Database Entry 84. http:// www.ifao.egnet.net/bases/cachette/?id=84 (Version 2, October 30, 2015).

Darnell, J.C. 2006 The Inscription of Queen Katimala at Semna: Textual Evidence for the Origins of the Napatan State. Yale Egyptological Studies 7. Yale University Press.

Davies, W.V. 2001 Kurgus 2000: The Egyptian Inscriptions. Sudan \& Nubia 5:46-58.

-_- 2014 From Halfa to Kareima: F.W. Green in Sudan. Sudan \& Nubia 18:2-19.

- - 2017 The Egyptians at Kurgus. In Nubia in the New Kingdom: Lived Experience, Pharaonic Control and Indigenous Traditions, ed. N. Spencer, A. Stevens, and M. Binder, pp. 65-105. British Museum Publications on Egypt and Sudan 3. Peeters.

Doyen, F. and L. Gabolde 2017 Egyptians versus Kushites: The Cultural Question of Writing or Not. In Nubia in the New Kingdom: Lived Experience, Pharaonic Control and Indigenous Traditions, ed. N. Spencer, A. Stevens, and M. Binder, pp. 149-58. British Museum Publications on Egypt and Sudan 3. Peeters.

Dunham D. 1970 The Barkal Temples. Museum of Fine Arts (Boston).

Edwards, D.N. 2004 The Nubian Past: An Archaeology of the Sudan. Routledge.

Eide, T., T. Hägg, R.H. Pierce, and L. Török eds. 1994 Fontes Historiae Nubiorum: Textual Sources for the History of the Middle Nile Region between the Eighth Century BC and the Sixth Century AD, v. 1: From the Eighth to the Mid-Fifth Century BC. Department of Classics, University of Bergen.

eds. 1996 Fontes Historiae Nubiorum: Textual Sources for the History of the Middle Nile Region between the Eighth Century BC and the Sixth Century AD, v. 2: From the Mid-Fifth to the First Century BC. Department of Greek, Latin and Egyptology, University of Bergen.

Emberling, G. 2014 Pastoral States: Toward a Comparative Archaeology of Early Kush. Origini 36:125-56.

Fabre, D. 2012 “Tous ceux qui ont élevé un sanctuaire à Zeus thébain (...) considèrent les béliers comme sacrés." La campagne de fouilles 2012 de l'IEASM à Thônis-Héracléion et "l'image vivante de culte" d'Amon. http://www.ieasm.org/downloads/

IEASM_religion_Belier_Amon_df.pdf. Accessed December 2016.

Fischer-Elfert, H.-W. 1997 Lesefunde im literarischen Steinbruch von Deir el-Medineh. Kleine Ägyptische Texte 12. Harrassowitz. 
Francigny, V. and A. de Voogt 2014 Jeux de la nature en dépôts votifs et funéraires dans les royaumes nubiens. Journal of Egyptian Archaeology 100:233-43.

(p. 364) Gabolde, L. 2018a Insight into the Perception of the Divine and Royal Powers among the Kushites and the Egyptians. In Nubian Archaeology in the XXIst Century: Proceedings of the Thirteenth International Conference for Nubian Studies, ed. M. Honegger, pp. 91-103. Orientalia Lovaniensia Analecta 273. Peeters.

Gabolde, L. 2018b Karnak, Amon-Rê. La genèse d'un temple, la naissance d'un dieu. Bibliothèque d'Étude 167. Institut Français d'Archéologie Orientale.

Gabolde, M. 1995 L'inondation sous les pieds d'Amon. Bulletin de l'Institut Français d'Archéologie Orientale 95:235-58.

Gauthier, H. 1912 Le temple de Ouadi es-Sebouâ. Les temples immergés de la Nubie. Institut Français d'Archéologie Orientale.

Goedicke, H. 1972 Review of The Barkal Temples, excavated by George Andrew Reisner. American Journal of Archaeology 76:89.

Griffith, F.L. 1922 Oxford Excavations in Nubia 2, parts VIII-XVII: Napata, Sanam Temple, Treasury, and Town. Liverpool Annals of Archaeology and Anthropology 9:67-124.

Griffith, F.L. and J.W. Crowfoot 1911 The Island of Meroe and Meroitic Inscriptions, v. 1: Sôba to Dangêl. Archaeological Survey of Egypt 19. Egypt Exploration Fund.

Griffith, F.L. and H. Thompson 1904 The Demotic Magical Papyrus of London and Leiden. H. Grevel.

Grimal, N.-C. 1981 Quatre stèles napatéennes au Musée du Caire JE 48863-48866. Mémoires de l'Institut Français d'Archéologie Orientale 106.

Guermeur, I. 2005 Les cultes d'Amon hors de Thèbes. Bibliothèque de l'École des Hautes Études, Sciences Religieuses 123.

Habachi, L. 1960 Five Stelae from the Temple of Amenophis III at Es-Sebua' now in the Aswan Museum. Kush 8:45-52.

Hein, I. 1991 Die ramessidische Bautätigkeit in Nubien. Göttinger Orientforschung IV(22). Harrassowitz.

Hintze, F. 1971 Musawwarat es Sufra I(2): Der Löwentempel. Akademie Verlag.

Jacquet-Gordon, H., C. Bonnet, and J. Jacquet 1969 Pnubs and the Temple of Tabo on Argo Island. Journal of Egyptian Archaeology 55:103-11.

Kemp, B.J. 1997 Why Empires Rise. Review Feature: Askut in Nubia by Stuart Tyson Smith. Cambridge Archaeological Journal 7(1):125-31. 


\section{The Amun Cult and Its Development in Nubia}

Kendall, T. 1988 The Cliff Shrine of Taharqa and the 'Uraeus' on Gebel Barkal. In Fifth International Congress of Egyptology: Abstracts of Papers, pp. 153-54.

- - 1999 The Origin of the Napatan State: El Kurru and the Evidence for Royal Ancestors. Studien zum antiken Sudan, ed. S. Wenig, pp. 3-117. Meroitica 15. Harrassowitz.

- - 2004 The Monument of Taharqa on Gebel Barkal. In Neueste Feldforschungen im Sudan und in Eritrea. Akten des Symposiums Berlin, ed. S. Wenig, pp. 1-46. Meroitica 21. Harrassowitz.

2008 Why Did Taharqa Build his Tomb at Nuri? In Between the Cataracts: Proceedings of the 11 th Conference for Nubian Studies, ed. W. Godlewski and A. Łajtar, Part 1, pp. 117-47. Polish Archaeology in the Mediterranean Supplement Series 2.1. Warsaw University.

\section{-_- 2017 B 700-Sub Chapels: Talatat Enclosures for the Aten Cult. http:// www.jebelbarkal.org/frames/B700subchapels.pdf (April 28, 2017).}

Kendall, T., El-Hassan Mohamed, H. Wilson, J. Haynes, and D. Klotz 2017 Jebel Barkal in the New Kingdom: An Emerging Picture. In Nubia in the New Kingdom: Lived Experience, (p.365) Pharaonic Control and Indigenous Traditions, ed. N. Spencer, A. Stevens, and M. Binder, pp. 155-88. British Museum Publications on Egypt and Sudan 3. Peeters.

Kendall, T. and P. Wolf, P. 2011 B 600: A Temple of Thutmose IV at Jebel Barkal. In La pioche et la plume. Autour du Soudan, du Liban et de la Jordanie. Hommages archéologiques à Patrice Lenoble, ed. V. Rondot, F. Alpi, and F. Villeneuve, pp. 237-59. Presses de l'Université Paris-Sorbonne.

Kleinitz, C. 2012 Rock Art at the Fourth Nile Cataract: An Overview. In Proceedings of the Third International Conference on the Archaeology of the Fourth Nile Cataract, ed. H-P. Wotzka, pp. 33-50. Africa Praehistorica 22. Heinrich-Barth-Institut.

Kormysheva, E. 1994 Le nom d'Amon sur les monuments royaux de Kouch. In Hommages à Jean Leclant, v. 2: Nubie, Soudan, Éthiopie, ed. C. Berger, G. Clerc, and N. Grimal, pp. 251-61. Bibliothèque d'Étude 106(2). Institut Français d'Archéologie Orientale.

-_- 1999 Amun of Pnubs on the Plaques from Kush. In Recent Research in Kushite History and Archaeology: Proceedings of the 8th International Conference for Meroitic Studies, ed. D.A. Welsby, pp. 285-91. British Museum Occasional Paper 131.

- - 2004 On the Origin and Evolution of the Amun Cult in Nubia. In Nubian Studies 1998: Proceedings of the Ninth International Conference of Nubian Studies, ed T. Kendall, pp. 109-33. Department of African-American Studies, Northeastern University.

Kröper, K., S. Schoske, and D. Wildung eds. 2011 Königsstadt Naga. Grabungen in der Wüste des Sudan. Naga-Projekt (Berlin). 


\section{The Amun Cult and Its Development in Nubia}

Leclant, J. 1949 "Per Africae Sitientia". Témoignages des sources classiques sur les pistes menant à l'oasis d'Ammon. Bulletin de l'Institut Français d'Archéologie Orientale 49:193253.

Lepsius, K.R. 1880 Nubische Grammatik, mit einer Einleitung über die Volker und Sprachen Afrika's. W. Hertz.

Lohwasser, A. 2011 Devil and God: The Crocodile in Kush. In La pioche et la plume. Autour du Soudan, du Liban et de la Jordanie. Hommages archéologiques à Patrice Lenoble, ed. V. Rondot, F. Alpi, and F. Villeneuve, pp. 383-89. Presses de l’Université Paris-Sorbonne.

Macadam, M.F.L. 1949 The Temples of Kawa, v. 1: The Inscriptions. Oxford University Press.

1955 The Temples of Kawa, v. 2: History and Archaeology of the Site. Oxford University Press.

Morkot, R. 2003 On the Priestly Origin of the Napatan Kings: The Adaptation, Demise and Resurrection of Ideas in Writing Nubian History. In Ancient Egypt in Africa, ed. D. O'Connor and A. Reid, pp. 151-68. UCL Press.

Näser, C. 2004 The Small Finds. In The Capital of Kush, v. 2: Meroe Excavations 19731984, P.L. Shinnie and J.R. Anderson, pp. 215-311. Meroitica 20. Harrassowitz.

Onderka, P. 2014 Wad ben Naga: A History of the Site. Sudan \& Nubia 18:83-92.

Pamminger, P. 1992 Amun und Luxor-Der Widder und das Kultbild. Beiträge zur Sudanforschung 5:93-140.

Porter, R. and B. Moss 1952 Topographical Bibliography of Ancient Egyptian Hieroglyphic Texts Reliefs, and Paintings, v. 7: Nubia, the Deserts, and Outside Egypt. Griffith Institute. http://www.griffith.ox.ac.uk/topbib/pdf/pm7.pdf.

Posener, G. 1936 Catalogue des ostraca hiératiques littéraires de Deir el-Médineh, v. 1: Documents de fouilles de l'Institut Français d'Archéologie Orientale 1.

Priese, K.-H. 1974 Die Statue des napatanischen Königs Aramatelqo (Amtelqa). Berlin, Ägyptisches Museum Inv.-Nr. 2249. In Festschrift zum 150 jährigen Bestehen des Berliner Ägyptischen Museums Berlin, pp. 211-32. Akademie Verlag.

(p. 366) Quaegebeur, J. 1986 Amenophis nom royal et nom divin. Revue d'Égyptologie 37:97-106.

Reisner, G.A. 1923a Excavations at Kerma 1-3. Harvard African Studies V. Peabody Museum of Harvard University.

-_- 1923b Excavations at Kerma 4-5. Harvard African Studies VI Peabody Museum of Harvard University.

Page 22 of 28

PRINTED FROM OXFORD HANDBOOKS ONLINE (www.oxfordhandbooks.com). (c) Oxford University Press, 2018. All Rights Reserved. Under the terms of the licence agreement, an individual user may print out a PDF of a single chapter of a title in Oxford Handbooks Online for personal use (for details see Privacy Policy and Legal Notice). 
-—- 1931 Inscribed Monuments from Gebel Barkal (1). Zeitschrift für ägyptische Sprache 66:76-100.

Reisner, G.A. and M.B. Reisner 1933 Inscribed Monuments from Gebel Barkal Part 3: The Stela of Sety I. Zeitschrift für ägyptische Sprache 69(2):73-78.

Rilly, C. 2010 La méroïtique et sa famille linguistique. Peeters.

- - - in prep. Arnekhamani's Sistrum: New Insights on the Appearance of the Meroitic Script. Paper presented at the 12th International Conference for Meroitic Studies, Prague (2016).

Rilly, C. and V. Francigny 2013 Sedeinga 2012: A Season of Unexpected Discoveries. Sudan \& Nubia 17:61-65.

Ritner, R.K. 2009 The Libyan Anarchy: Inscriptions from Egypt's Third Intermediate Period. Writings from the Ancient World 21. Society of Biblical Literature.

Rocheleau, C. 2008 Amun Temples in Nubia: A Typological Study of New Kingdom, Napatan and Meroitic Temples. BAR International Series 1850. Archaeopress.

Rondot, V. 2008 A Hitherto Unknown Rock Stela in the Name of Senusret III at Nauri (Mahas Country). Kush 19:179-84.

-_- 2012 El-Hassa. Un temple à Amon dans l'île de Meroe au I ${ }^{\mathrm{er}}$ siècle de notre ère. Comptes Rendus de l'Académie des Inscriptions et Belles-Lettres 2012(1):167-82.

Rondot, V. and L. Gabolde 2018 Les dhnw.t de Kouch. In Hommages à L. Török, in T.A. Bács, Á. Bollók, T. Vidap (éd.) Across the Mediterranean - along the Nile, Studies in Egyptology, Nubiology and Late Antiquity Dedicated to László Török on the Occasion of His 75th Birthday, pp. 391-410. Institute of Archaeology, Research Centre for the Humanities, Hungarian Academy of Sciences and Museum of Fine Arts.

Rondot, V. and G. Nogara in prep. Meroitic Model "Temple and Ceremonial Palace": The Archaeological Demonstration at El-Hassa. Paper presented at the 12th International Conference for Meroitic Studies, Prague (2016).

Säve-Söderbergh, T. 1960 The Paintings in the Tom of Djehuty-hetep at Debeira. Kush $8: 25-44$.

Schiff-Giorgini, M., J. Leclant, C. Robichon, and N. Beaux 1998 Soleb, v. 5: Le temple, basreliefs et inscriptions. Institut Français d'Archéologie Orientale.

Smith, H.S. 1972 The Rock Inscriptions of Buhen. Journal of Egyptian Archaeology 58:4382.

1976 The Fortress of Buhen: The Inscriptions. Egypt Exploration Society Excavation Memoir 48. 
Smith S.T. 1998 Nubia and Egypt: Interaction, Acculturation, and Secondary State Formation from the Third to First Millennium B.C. In Studies in Culture Contact, Interaction, Culture Change, and Archaeology, ed. J.G. Cusick, pp. 256-87. Center for Archaeological Investigations Occasional Paper 25. Southern Illinois University.

Thiem, A.-C. 2000 Speos von Gebel es-Silsileh, Analyse der architektonischen und ikonographischen Konzeption im Rahmen des politischen und legitimatorischen Programmes der Nachamarnazeit. Ägypten und Altes Testament 47. Harrassowitz.

(p. 367) Thill, F. 1997 Les premiers dépôts de fondation de Saï. Cahier de Recherches de l'Institut de Papyrologie et d'Égyptologie de Lille 17(2):105-17. Actes de la VIII ${ }^{\mathrm{e}}$ conférence internationale des études nubiennes.

Török, L. 1995 The Emergence of the Kingdom of Kush and her Myth of the State in the First Millennium BC. Actes de la VIII ${ }^{\mathrm{e}}$ conférence internationale des études nubiennes. Cahier de Recherches de l'Institut de Papyrologie et d'Égyptologie de Lille 17(1):203-28.

1997a The Kingdom of Kush: Handbook of the Napatan-Meroitic Civilization. Handbuch der Orientalistik 1(31). Brill.

-_- 1997b Meroe City: An Ancient African Capital. John Garstang's Excavations in the Sudan. Egypt Exploration Society Occasional Publications 12.

-_- 2002 The Image of the Ordered World in Ancient Nubian Art: The Construction of the Kushite Mind, 800 BC-300 AD. Probleme der Ägyptologie 18. Brill.

- - 2009 Between Two Worlds: The Frontier Region between Ancient Nubia and Egypt $3700 B C-A D$ 500. Probleme der Ägyptologie 29. Brill.

Valbelle, D. 2003a L'Amon de Pnoubs. Revue d’Égyptologie 54:191-217.

-—- 2003b Kerma, les inscriptions. Genava n.s. 49:229-34.

—__ 2009 Kerma, les inscriptions et la statuaire. Genava n.s. 57:109-19.

Valbelle, D. and C. Bonnet 2000 Les sanctuaires de Kerma du Nouvel Empire à l'époque méroïtique, Comptes Rendus de l'Académie des Inscriptions et Belles-Lettres, juillet-octobre, pp. 1099-1120.

- - 2003 Amon à Kerma. In Hommages à Fayza Haikal, ed. N. Grimal, A. Kamel, and C.M. Sheikholeslami, pp. 289-304. Bibliothèque d’Étude 138. Institut Français d’Archéologie Orientale.

Welsby, D.A. 1996 The Kingdom of Kush: The Napatan and Meroitic Empires. British Museum.

Wenig, S. 1978 Africa in Antiquity: The Arts of Ancient Nubia and the Sudan, v. 2: The Catalogue. The Brooklyn Museum. 
——— 2001 Musawwarat es-Sufra: Interpreting the Great Enclosure. Sudan \& Nubia 5:71-86.

2013 Die Heraufkunft der 25. Dynastie. In Die Kulturen Nubiens-ein afrikanisches Vermächtnis, ed. S. Wenig and K. Zibelius-Chen, pp. 157-71. J.J. Röll.

Wildung, D. 1984 Sésostris und Amenemhat. Ägypten im Mittleren Reich. Hirmer.

-_- 1999 Die Stadt in der Steppe. Grabungen des ägyptischen Museums Berlin in Naga-Sudan. Stiftung Preussischer Kulturbesitz.

Williams, B. 2006 The Cave Shrine and the Gebel. In Timelines: Studies in Honour of Manfred Bietak, v. 3, ed. E. Czerny, I. Hein, H. Hunger, D. Melman, and A. Schwab, pp. 149-58. Orientalia Lovaniensia Analecta 149. Peeters.

- - 2007 The Adoption and Rejection of Egyptian Symbolic Culture in Nubia. In Mélanges offerts à Francis Geus, ed. B. Gratien. Cahier de Recherches de l'Institut de Papyrologie et d'Égyptologie de Lille 26:399-410.

Wolf, P. 2006 Temples in the Meroitic South-Some Aspects of Typology, Cult and Function. In Acta Nubica: Proceedings of the $X$ International Conference of Nubian Studies, ed. I. Caneva and A. Roccati, pp. 239-62. Libreria dello Stato.

Wüthrich, A. 2010 Éléments de théologie thébaine. Les chapitres supplémentaires du Livre des Morts. Studien zum Altägyptischen Totenbuch 16. Harrassowitz.

(p. 368) - - 2015 Édition synoptique et traduction des chapitres supplémentaires du Livre des Morts 162 à 167. Studien zum Altägyptischen Totentexten 19(1-2). Harrassowitz.

Yellin, J.W. 1995 Egyptian Religion and its Ongoing Impact on the Formation of the Napatan State. A Contribution to László Török's Main Paper: The Emergence of the Kingdom of Kush and her Myth of the State in the First Millennium BC. VIII ${ }^{\mathrm{e}}$ Conférence Internationale des Études Nubiennes. Cahiers de Recherches de l'Institut de Papyrologie et d’Égyptologie de Lille 17(1):243-63.

Yoyotte, J. 2005 Bélier. In Le bestiaire des Pharaons, ed. P. Vernus and J. Yoyotte, pp. 47190. Perrin.

Zibelius-Chen, K. 2011 "Nubisches" Sprachmaterial in hieroglyphischen und hieratischen Texten. Meroitica 25. Harrassowitz.

\section{Notes:}

(1.) For example, the Ramesside ostracon D. el-M. 1072 (Posener 1936:40; pl. 40; FischerElfert 1997:1-4; Zibelius-Chen 2011:160) makes a clear allusion to Jebel Barkal as source of the Nile in connection with an epithet of Amun and with the god Amun himself: "As to 'Degal,' (it is) the name of the harbor and '(Jebel) Ta-waww [in Egyptian "remote 


\section{The Amun Cult and Its Development in Nubia}

land"],' (it is) the name of the escarpment. As to 'Nakhysmekas,' (it is) the name of the goddess, (that is) the water from which Amun went out in the land of Kush." The toponym Ta-waww echoes the more complete local (Nubian) designation nswt-T3wy "of the sacred (pure) mountain" ( $\underline{d} w$ - $w^{c} b$; see Thiem 2000:23 n. 78) in the Barkal stela of Thutmose III (Urk. IV:1238, 5-7). Chapter 163 of the Book of the Dead (Wüthrich 2010:115, 118, 13233, 146-47; Wüthrich 2015: v. 19(1):105-107, 19(2):56) equally states, about Amun, that "It is him who rests to the northwest of Napata's escarpment in Nubia." And the link between Amun and Jebel Barkal through the toponym nswt-T3wy is once more displayed on a passage of the year 11 stela of Seti I discovered on the site (Khartoum SN $2856=$ Reisner and Reisner 1933:73-78, pl. 8 = KRI I:76, 7-8 (l. 19)): “O Lords [...and Goddess] who preside over the (deified Cobra) of Nesut-Tawy (= Jebel Barkal)." The Aspelta stela of year 1 from Jebel Barkal (Eide et al. 1994:237, l. 12 (37)) moreover states that: "Amen-Rê, lord of the Thrones of Two-lands, who resides in Pure-mountain (Jebel Barkal)-he is a god of Kush .... He has been the god of the kings of Kush since the time of Rê." Much later, Greek papyri claimed "[Hail] to you, Khonsu in Thebes...the son of the Ethiopian..." (Betz 1992:209), or declared in their Greek and Demotic versions (Griffith and Thompson 1904: 193, $\mathrm{v}^{\circ}$, col. XX): "Ho? Amun, this lofty male, this male of Ethiopia (3kš) who came down from Meroe to Egypt."

(2.) (1) A finely elaborated glazed quartz ram head found by Reisner in tumulus KIII of Kerma (Boston, MFA 20.118; Reisner 1923a:139, no. XIII, 1923b:51) and dated to Kerma Classique (Wildung 1984:181-82; 1999:102-103, no. 104; Kormysheva 2004:113). However, many items from the grave, including other glazed quartzite objects, could as well originate from Egypt, by trade or looting, though some may also have been produced at Kerma by Egyptian expatriates (Reisner 1923a:17, 1923b:49-50). The ram head itself has no equivalent in the contemporary Nubian zoomorphic production. (2) Remains of rams found by Bonnet in burials dated to Kerma Ancien (Bonnet 1984:15-17; Chaix 1993) and showing on one of the ram's heads a specific spherical ornament attached between the horns have also been put forward. However, the animals may also be part of a funerary ritual sacrifice (Chaix 2003) as there was not one single animal but several individuals and they were clearly buried in human tombs and together with the owner. (3) A supposed sheep-headed (?), female (?), pregnant (?) C-Group figurine from Askut (Los Angeles, Museum of Cultural History no. 400-1541; Wenig 1978:122 cat. no. 12) reused in a kind of Egyptian-influenced-style shrine with a cavetto cornice accompanied by an Egyptian stela is also questionable as it was not found in a genuine context, but was possibly borrowed. Its interpretation is ambiguous (the sheep's head is hardly recognizable) and it would be rather uncommon to see a female deity transformed into a male one. (4) An animal figurine from Aniba, dated to the C-Group and showing a quadruped with a globe between the horns (Wenig 1978:129 cat. no. 20), has also been put forward, but its zoological identification remains controversial (bull or ram?) whereas the spherical ornament is clearly worked like hair loops, not like a solar element. (5) A ram-headed pouring spout of a so-called "teapot"-vessel type from Tumulus III at Kerma (Wenig 1978:157, cat. no. 65) is also inconclusive as other animals-not deities-like the bull are also encountered for this kind of luxury pottery of almost certainly profane use. 
(3.) The (raging) bull (Thutmose I and III panels on the sacred rock of Kurgus: Davies 2001:48-49, 2017:73 Figure8) with oversized bull-hieroglyph of Kamutef. The bull is also associated with Amun of Sanam as "Amun-the-bull-lord-of-Nubia-T3-Sti" (Guermeur 2005: 521ff.).

(4.) Geese labelled "Amun" + epithets mentioned on a stela found at Kerma/Dokki-Gel (Valbelle 2009:113) in direct line of the Egyptian tradition, apparently not attested in Napatan or Meroitic spheres.

(5.) The crocodile suggested by Kormysheva (2004:122-23) as a specifically Nubian form of the deity, on the basis of a representation at Abu-Simbel (Porter and Moss 1952:106[VIII] identical with Champollion 1844:597 and 902); the other mention of this saurian aspect is however Theban (Coulon and Jambon 2015). In Kush the crocodile may have occasionally been associated with the ram-headed Amun of Pnubs but once in subdued position and twice as part of private names (Sobek-hotep and Sobek-em-hat; see Kormysheva 1999:290 Figure 8 for the first and figs. 6-7 for the others); there is in fact no real clue that the crocodile was an aspect of this god, rather than just an associated deity or a dreaded creature as convincingly shown by Lohwasser 2011.

(6.) It has been suggested by Kendall (2008), for whom the pinnacle of Jebel Barkal would represent a uraeus (as well as an ithyphallic Amun), that the cobra was a form of Amun. Though the cobra may indeed be a symbolic interpretation of Barkal's pinnacle-associated with the god-it is however not certain that it represented Amun himself. The association of the cobra with the pinnacle is attested in numerous reliefs (Kendall 1988, 2004, 2008) and in the above-quoted passage of Sety I's stela where nswt-T3wy (i.e., here Jebel Barkal) is written with a serpent as determinative (KRI I:76,8). An amulet found in tomb $\mathrm{K}$ 51 at El-Kurru (Boston MFA 21.304, obverse) shows a cobra apparently labelled Imn(- $\left.R^{c}\right)$, $n b$, "Amun(-Ra) the Lord" and a bronze statuette of a rearing ram-headed uraeus, from Barkal, B 700, room 704 (Boston MFA 24.960, Dunham 1970:71, no. 16-3-225) is one of the punctual, rare, and late representations of a possible symbolic symbiosis of Amun with the cobra and, eventually, the pinnacle ( $\mathrm{T}$. Kendall noticed also the criocephalic uraeus of the smiting king on the pylon of Beg. $\mathrm{N} 19$ ).

(7.) Quoted as "Beautiful wonder" (bi3t $n f r$ ) and performed by his father Amun for Amannote-erike (<CE: Reference Eide et al. 1996 has not been provided in the Bibliography. Please check. > Eide et al. 1996:403 (71); Török, 1997a:193, 217).

(8.) e.g., Piye (Piankhy): Eide et al. 1994:55, 58 (8); Eide et al. 1994:77 (9); Taharqo, (Kawa IV): Eide et al. 1994:140-41 (21); Eide et al. 1994:147 (22); Anlamani: Eide et al. 1994:219 (34).

(9.) Ramesside ostracon D. el-M. 1072 states: "As to 'Nakhysmekas,' (it is) the name of the goddess, (that is) the water from which Amun went out in the land of Kush." (Posener 1936:40, pl. 40; Gabolde 2018a:92-95; Gabolde and Rondot 2018:393, 396-97) 
(10.) e.g., the inundation stela of year 6 of Taharqo (Kawa V: Eide et al. 1994:150 (22)): "When the time for the rising (7) of the inundation came, it continued rising greatly each day and it passed many days rising at the rate of one cubit every day. It penetrated the hills of South-land, it overtopped the mounds of North-land, and the land was (again) Primeval Waters, an inert (expanse), without land being (8) distinguishable from river. It rose to a height of 21 cubits, one palm, and $21 / 2$ digits at the harbor of Dominion (Thebes)....(9) Well, then, the sky (even) rained in Bow-land (Nubia) and adorned all the hills....The inundation came as a cattle-thief, and flooded this whole land" (see also, among many others, the hymn to Amun from Temple of T Kawa, reign of Taharqo: Török 2002:85).

(11.) e.g., Piye (Piankhy) triumphal stela: Eide et al. 1994:71-72; 95 (9); Amannote-erike, Kawa IX: Eide et al. 1996:404-405 (71).

(12.) "The Lord who made what exists, Amun, who fashioned men...etc." (Taharqo hymn to Amun from the temple of T Kawa: Török 2002:85 after Macadam 1955:102, pls. XXIV and XLVI, among many others).

\section{Luc Gabolde}

Luc Gabolde, Centre National de la Recherche Scientifique 